\title{
Dipeptide Synthesis in Biphasic Medium: Evaluating the use of Commercial Porcine Pancreatic Lipase Preparations and the Involvement of Contaminant Proteases
}

\author{
Cleber W. Liria, Carolina D. Romagna, Nicolas N. Rodovalho, \\ Sandro R. Marana and M. Terêsa M. Miranda* \\ Departamento de Bioquímica, Instituto de Química, Universidade de São Paulo, CP 26077, \\ 05513-970 São Paulo-SP, Brazil
}

\begin{abstract}
Sínteses bem sucedidas de dipeptídeos a partir de Ac- $L$-Tyr-OEt ou Z- $L$-X-OMe (X: Asp, Tyr, Phe, Arg, Lys ou Thr) e glicina amidada em meio reacional bifásico foram realizadas usando dois tipos de preparações comerciais de lipase pancreática suína (PPL) (bruta (cPPL) e purificada (pPPL)). Nas mesmas condições reacionais, a $\alpha$-quimotripsina, protease pancreática que também apresenta atividade esterásica, catalisou a síntese de Ac- $L$-Tyr-Gly- $\mathrm{NH}_{2}$ com alta produtividade. Na maioria das sínteses também ocorreu a hidrólise do produto formado. Eletroforese em gel de poliacrilamida, ensaios enzimáticos com substratos cromogênicos específicos e cromatografia de exclusão molecular demonstraram que cPPL e pPPL apresentam proteases contaminantes e, portanto, atividades esterásica e amidásica. Em conjunto, esses resultados indicam que tais proteases, e não a PPL, possam ser os catalisadores majoritários da síntese da ligação peptídica quando ésteres de $N^{\alpha}$-acil- $L$-aminoácidos e preparações comerciais de PPL são usados. Por outro lado, tais dados não contradizem a possibilidade de usar cPPL como fonte barata de catalisadores para a síntese de dipeptídeos em condições reacionais brandas.
\end{abstract}

Dipeptide syntheses starting from Ac- $L$-Tyr-OEt or Z-L-X-OMe (X: Asp, Tyr, Phe, Arg, Lys or Thr) and glycine amide in biphasic reaction media were achieved using two commercially available porcine pancreatic lipase (PPL) preparations (crude (cPPL) and purified PPL (pPPL)). Under the mild conditions employed, $\alpha$-chymotrypsin, a pancreatic protease that also presents esterase activity, catalyzed Ac- $L$-Tyr-Gly- $\mathrm{NH}_{2}$ synthesis with high productivity. Product hydrolysis also occurred in most of the syntheses studied. Polyacrylamide gel electrophoresis, enzymatic assays employing specific chromogenic substrates and size-exclusion chromatography revealed that cPPL and pPPL contain contaminant proteases and, therefore, exhibit esterase and amidase activities. Overall, these data indicate that those contaminants may be the main catalysts of peptide bond synthesis when $N^{\alpha}$-blocked- $L$-amino acid esters and the commercial PPL preparations are used. On the other hand, such data do not contest the possibility of using such enzyme preparations as an inexpensive source of catalysts for dipeptide synthesis under soft conditions.

Keywords: biocatalysis, enzymes, peptide bond synthesis, $n$-hexane

\section{Introduction}

In the last decade, interest in environment friendly technologies has increased drastically. As a result, the ability of enzymes to catalyze reactions required for the manufacture of fine chemicals has been explored extensively. ${ }^{1}$

Proteases that also present esterase activity have been widely used to catalyze reactions related to peptide synthesis, such as ester hydrolysis, esterification, transesterification and peptide bond formation. ${ }^{2,3}$ However,

*e-mail: mtmirand@iq.usp.br it is well known that the main concern in protease-catalyzed peptide bond synthesis is protease-catalyzed product consumption. ${ }^{4-6}$ Therefore, the following approaches have been used to minimize such an undesirable reaction: (i) continuous removal of the product from the reaction medium by precipitation ${ }^{7,8}$ or extraction; ${ }^{9}$ (ii) freezing of the reaction; ${ }^{10}$ (iii) use of an esterified $N$-acyl-amino acid or $N^{\alpha}$-acyl-peptide as acyl donor; ${ }^{11}$ (iv) use of a mimetic substrate; ${ }^{12}$ and $(v)$ use of a chemically modified or mutant protease. ${ }^{13}$

On the other hand, many authors have attempted to use other biocatalysts for peptide bond synthesis. ${ }^{14}$ Among them are the lipases (EC 3.1.1.3), enzymes that primarily 
mediate the hydrolysis of triacylglycerides into mono, diacylglycerides, fatty acids and glycerol through the formation of an acyl-enzyme intermediate followed by deacylation with water. ${ }^{15}$ Indeed, it has been reported the use of commercial lipases in peptide bond syntheses starting from $N^{\alpha}$-blocked-amino acid esters (acyl donors) and amino acid or peptide amides (acyl acceptors). ${ }^{16-19}$ Nevertheless, many authors have claimed that these enzyme preparations present amidase activity, due to contaminant proteases. ${ }^{20,21}$ Hence, they could also lead to the undesired hydrolysis of the product formed.

Within this context and knowing that the market for fine chemicals such as synthetic peptides is very healthy ${ }^{22}$ and requires cleaner technologies, we evaluated the use of porcine pancreatic lipase (PPL) preparations in peptide bond formation in biphasic reaction media as well as the involvement of the contaminant proteases in the process. For these purposes, two commercially available PPL preparations (crude, cPPL, and purified, pPPL) were used in dipeptide synthesis trials starting from a few $N^{\alpha}$-blocked$L$-amino acid esters (acyl donors) and glycine amide (acyl acceptor), these enzyme preparations were analyzed by gel electrophoresis and had their lipase activity measured. cPPL was also assayed against chromogenic substrates typically recognized by proteases and submitted to size-exclusion liquid chromatography.

\section{Experimental}

\section{Chemicals and enzymes}

Crude PPL (cPPL; Type II, L-3126), $N^{\alpha}-$ benzyloxycarbonyl-glycyl- $L$-phenylalanine (Z-Gly- $L$ Phe) and the diagnostic kit for the standard titrimetric determination of lipase activity were obtained from Sigma Chemical Co. (St. Louis, MO, USA). The purified PPL (pPPL; IC398) was from Elastin Products Co. (Owensville, MO, USA). $\alpha$-Chymotrypsin and trypsin were donated by Biobrás/Novo Nordisk Brazil (Montes Claros, Brazil). Tris(hydroxymethyl)aminomethane hydrochloride (Tris$\mathrm{HCl}$ ), spectroscopy-grade trifluoroacetic acid (TFA), analytical-grade $n$-hexane, synthesis-grade triethylamine (TEA) and high-performance liquid chromatography (HPLC)-grade acetonitrile (ACN) were purchased from Merck KGaA (Darmstadt, Germany). The $N^{\alpha}$-acyl- $L$-amino acid esters Ac-Tyr-OEt, Z-Asp-OMe, Z-Phe-OMe, Z-Thr$\mathrm{OMe}, \mathrm{Z}$-Arg-OMe, Z-Lys-OMe (where, Ac is acetyl, Z is benzyloxycarbonyl, Me is methyl, Tyr, Asp, Phe, Thr, Arg and Lys are tyrosine, aspartic acid, phenylalanine, threonine, arginine and lysine, respectively) and glycine amide hydrochloride $\left(\mathrm{Gly}-\mathrm{NH}_{2} \cdot \mathrm{HCl}\right)$ were acquired from
Bachem (Torrance, CA, USA). $N^{\alpha}$-benzoyl- $D L$-arginine- $p$ nitroanilide (Bz- $D L-\operatorname{Arg}-p \mathrm{NA}$ ) and $N^{\alpha}$-benzoyl- $L$-tyrosine$p$-nitroanilide (Bz- $L$-Tyr- $p$ NA) were obtained from Nakarai Chemicals Ltd. (Kyoto, Japan). The compound $p$-nitrophenyl palmitate ( $p$ NPP) was purchased from Fluka Reidel-deHaën (Seelze, Germany).

Lipase activity in $C P P L$ and PPPL using olive oil as substrate

One milliliter of enzyme solution $\left(2 \mathrm{mg} \mathrm{mL}^{-1}\right.$ in $0.2 \mathrm{~mol} \mathrm{~L}^{-1}$ Tris-HCl buffer, $\mathrm{pH} 8$ ), $2.5 \mathrm{~mL}$ of water, $1.0 \mathrm{~mL}$ of buffer and $3.0 \mathrm{~mL}$ of $50 \%$ olive oil//water were incubated for $6 \mathrm{~h}$ at $37^{\circ} \mathrm{C}$ under orbital shaking at $300 \mathrm{rpm}$. The amount of fatty acids formed in the mixture was determined by titration with $0.05 \mathrm{~mol} \mathrm{~L}^{-1} \mathrm{NaOH} /$ water, using $0.9 \%$ thymolphthalein as indicator. ${ }^{23}$ One unit of lipase activity was defined as the amount of enzyme that, under test conditions, releases $1 \mu$ equiv. of fatty acid per hour. Therefore, lipase activity was expressed as units per $\mathrm{mg}$ of solid $\left(\mathrm{U} \mathrm{mg}^{-1}\right)$.

Lipase activity in $c P P L$ and $p P P L$ using $p N P P$ as substrate

Used only for qualitative purpose: to screen the fractions resultant from size-exclusion liquid chromatography of cPPL. ${ }^{24} p$ NPP (non-colored substrate; $75.5 \mathrm{mg}$ ) was dissolved in isopropanol $(100 \mathrm{~mL})$. An aliquot of the resulting solution was diluted $(1: 10, \mathrm{v}: \mathrm{v})$ in 55 mmol L-1 phosphate buffer, $\mathrm{pH} 7.0$, containing $1.33 \%$ 4-(1,1,3,3-Tetramethylbutyl)phenyl-polyethyleneglycol (Triton X-100). Fifty microliters-aliquots of such mixture were dispensed into a 96-well microtiter plate. Enzyme solution $(50 \mu \mathrm{L})$ previously incubated at $37{ }^{\circ} \mathrm{C}$ was added and the reaction was allowed to occur at $37{ }^{\circ} \mathrm{C}$. The formation of the yellow product (pNP) was monitored spectrophotometrically at $420 \mathrm{~nm}$.

Amidase activity against Bz-DL-Arg-pNA in cPPL

For the assay, ${ }^{25} 2.5 \mathrm{~mL}$ of $4 \mathrm{mmol} \mathrm{L}^{-1} \mathrm{Bz}-D L$-Arg- $p \mathrm{NA} /$ water and $0.3 \mathrm{~mL}$ of $0.03 \mathrm{mmol} \mathrm{L}^{-1}$ phosphate buffer, $\mathrm{pH} 8$, were placed in a $4.5-\mathrm{mL}$ quartz cuvette. Reaction at room temperature was initiated by adding $0.2 \mathrm{~mL}$ of cPPL solution (12.5 $\mu \mathrm{g} \mathrm{mL}^{-1}$ of $0.01 \mathrm{~mol} \mathrm{~L}^{-1} \mathrm{HCl} /$ water). Monitoring began immediately by following the increase of absorbance at $405 \mathrm{~nm}$ for 5 min on a Shimadzu UV160 1PC spectrophotometer (Shimadzu, Kyoto, Japan) connected to a microcomputer. One unit of activity was defined as the amount of cPPL, which, under test conditions, catalyzed the transformation of $1 \mu \mathrm{mol}$ of substrate per min. The enzyme activity was expressed as units per $\mathrm{mg}$ of solid $\left(\mathrm{U} \mathrm{mg}^{-1}\right)$. 
Amidase activity against Bz-L-Tyr-pNA in cPPL

For the assay, ${ }^{26} 2.8 \mathrm{~mL}$ of $12 \mathrm{mmol} \mathrm{L}{ }^{-1} \mathrm{Bz}-L$-Tyr$p \mathrm{NA} / 70 \mathrm{mmol} \mathrm{L}^{-1}$ phosphate buffer, $\mathrm{pH}$ 7.6, were placed in a $4.5 \mathrm{~mL}$ quartz cuvette. The reaction at $25{ }^{\circ} \mathrm{C}$ was initiated by adding $0.2 \mathrm{~mL}$ of cPPL solution $(0.5 \mathrm{mg}$ per $\mathrm{mL}$ of $0.01 \mathrm{~mol} \mathrm{~L}^{-1} \mathrm{HCl} /$ water). Monitoring was done as explained above. The enzyme activity was calculated and expressed as described above.

\section{Amidase activity against Z-Gly-L-Phe in $c P P L$}

The dipeptide ${ }^{27}$ was dissolved in $20 \mu \mathrm{L}$ of $80 \%$ $n$-hexane $/ 0.5 \mathrm{~mol} \mathrm{~L}^{-1}$ Tris- $\mathrm{HCl}$ buffer, $\mathrm{pH} 8$, providing a $0.02 \mathrm{~mol} \mathrm{~L}^{-1}$ solution. The reaction at $37{ }^{\circ} \mathrm{C}$ was started by adding $1 \mathrm{mg}$ of cPPL, followed by orbital shaking at $300 \mathrm{rpm}$ and monitoring immediately and after $1 \mathrm{~h}$. Briefly, the reaction medium was diluted with $980 \mu \mathrm{L}$ of $50 \%$ ACN/0.1\% TFA, pH 2.5. Duplicates were analyzed by reversed-phase (RP)-HPLC on a LDC Analytical system [a Constametric 3500, a Constametric 3200 pump, an AS 3000 Spectrasystem autosampler and an UV-Vis Spectromonitor, model 3100 (Thermo Separation Products, San Jose, CA, USA)] connected to a Vydac $\mathrm{C}_{18}(5 \mu \mathrm{m}$, $300 \AA$, $4.6 \mathrm{~mm} \times 25.0 \mathrm{~cm}$ ) column. The linear gradient employed ranged from 5 to $95 \% \mathrm{~B}$ in $30 \mathrm{~min}$ (solvent A: $0.1 \% \mathrm{TFA} /$ water; solvent B: $60 \% \mathrm{ACN} /$ solvent A) at a flow rate of $1 \mathrm{~mL} \mathrm{~min}^{-1}$. UV detection was at $210 \mathrm{~nm}$. The enzyme activity was calculated and expressed as described above.

\section{Gel electrophoresis}

The two commercial PPLs employed were analyzed by unidimensional polyacrylamide gel electrophoresis/ sodium dodecyl sulfate (SDS-PAGE) in a $15 \%$ polyacrylamide gel at $\mathrm{pH} 8.8$, following the protocol described by Sambrook and coworkers. ${ }^{28}$ A commercially available solution containing $\alpha$-lactalbumin, trypsin inhibitor, carbonic anhydrase, ovalbumin, albumin, and phosphorylase B (14,400-97,000 Da) was used as source of molecular weight markers. Commercially available Candida cylindracea lipases (CCLs) were used as references as they are considered highly purified. Purified pancreatic trypsin, $\alpha$-chymotrypsin and carboxypeptidase A were used as authentic standards (proteases that could be present in cPPL and pPPL samples). Proteins were stained with Coomassie Blue R-250 and destained in water:methanol:acetic acid ( $5: 4: 1$, by volume).

\section{General procedure for peptide bond formation}

The reaction was carried out in a volume of $20 \mu \mathrm{L}$ at a controlled temperature for a given time under orbital shaking at $300 \mathrm{rpm}$. In a typical procedure, $16 \mu \mathrm{L}$ of $n$-hexane was added to the acyl donor and the acyl acceptor (amounts required for a $0.05 \mathrm{~mol} \mathrm{~L}^{-1}$ and $0.5 \mathrm{~mol} \mathrm{~L}^{-1}$ final solution, respectively) placed in a plastic vial. TEA, equimolar to the acyl acceptor, was added to the resulting mixture. The reaction was started by adding $4 \mu \mathrm{L}$ of cPPL or pPPL solution $\left(0.25 \mathrm{mg}\right.$ of solid $\mu \mathrm{L}^{-1}$ of $0.5 \mathrm{~mol} \mathrm{~L}^{-1}$ Tris$\mathrm{HCl}$ buffer, $\mathrm{pH}$ 8). It was ended by dilution with $980 \mu \mathrm{L}$ of $50 \% \mathrm{ACN} / 0.1 \%$ TFA (only those with initial volumes intact: $0-80 \% n$-hexane).

Product identification and quantification were achieved by loading an aliquot of the diluted reaction on a Vydac $\mathrm{C}_{18}$ column $(5 \mu \mathrm{m}, 300 \AA$, $4.6 \mathrm{~mm} \times 25.0 \mathrm{~cm})$ connected to the aforementioned LDC analytical HPLC system and eluting under the following conditions: linear gradient from 5 to $95 \% \mathrm{~B}$ in $30 \mathrm{~min}$ (solvent A: $0.1 \%$ TFA/water; solvent B: ACN/solvent A) at flow rate of $1 \mathrm{~mL} \mathrm{m^{-1 }}$. UV detection was at $210 \mathrm{~nm}$. The peaks in the chromatograms were identified by coelution with authentic standards and, in most of the cases, also by RPHPLC coupled to a mass spectrometer (high resolution mass spectrometry using electrospray ionization; ESIMS). The quantities of the acyl donor $\left(N^{\alpha}\right.$-acyl- $L$-amino acid ester) and products ( $N^{\alpha}$-acyl- $L$-amino acid and/ or dipeptide) were calculated using standard curves (peak area $v s$. quantity) previously obtained. Exception was made for Z-Asp-Gly- $\mathrm{NH}_{2}$ synthesis trials as we ended, diluted and analyzed the reaction media with initial volumes intact (only those containing $0-80 \%$ $n$-hexane), identified the RP-HPLC peak corresponding to the desired product (dipeptide), calculated its area and plotted each area obtained against each $n$-hexane percentage employed to determine which would lead to the highest dipeptide synthesis yield.

The enzyme preparation employed in the synthesis of Z- $L$-Asp-Gly- $\mathrm{NH}_{2}$ was cPPL, the $n$-hexane contents were $0,10,40,60,70,80,90$ and $100 \%$ and the temperature was $37^{\circ} \mathrm{C}$. Reactions were performed in duplicate for $0,5,10$, 20, 30 and $40 \mathrm{~min}$, and 1, 2, 3, 4, 5, 6, 8, 24 and $48 \mathrm{~h}$.

As for the synthesis of Ac- $L$-Tyr-Gly- $\mathrm{NH}_{2}$ employing cPPL, pPPL and $\alpha$-chymotrypsin, all trials were performed in duplicate under the experimental conditions described in Table 1 for 0 and 5 min and 24, 48 and $72 \mathrm{~h}$.

Regarding the synthesis of other dipeptides using cPPL, all trials were performed in duplicate under experimental condition 1 described in Table 1 for 0, 5, 10, 20, 30 and 40 min, and 1, 2, 4, 8, 24 and 48 or $51 \mathrm{~h}$. 
Table 1. Ac-Tyr-Gly- $\mathrm{NH}_{2}$ synthesis trials performed



Ac-Tyr-OEt concentration: $0.05 \mathrm{~mol} \mathrm{~L}{ }^{-1}$; total volume: $20 \mu \mathrm{L}$; ${ }^{\mathrm{a}, \mathrm{c}}$ Lipase units in the reaction media: 48,19 respectively; ${ }^{\mathrm{b}} \mathrm{Gly}-\mathrm{NH}_{2} \cdot \mathrm{HCl}$ was pre-neutralized with TEA; ${ }^{\mathrm{d}}$ reaction in $0.5 \mathrm{~mol} \mathrm{~L}^{-1}$ Tris- $\mathrm{HCl}$ buffer, $\mathrm{pH} 8$.

It should be noted that the minimum time required for the reaction mixture to reach 22 or $37^{\circ} \mathrm{C}$ was 5 min and that standard deviations were calculated from the peptide synthesis yields obtained (whenever they exceeded $5 \%$, the reactions were repeated).

\section{Dipeptide purification and chemical characterization}

The products were purified by RP-HPLC using the aforementioned column, equipment and linear gradient. Solvent B contained the following percentages of $\mathrm{ACN}$ : $40 \%$ (Z-L-Arg-Gly-NH $\mathrm{N}_{2} \mathrm{Z}$ - $L$-Lys-Gly- $\mathrm{NH}_{2}$ and Z- $L$-Thr-

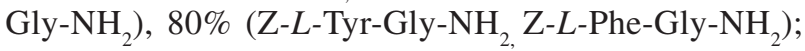
$20 \%$ (Ac- $L$-Tyr-Gly- $\mathrm{NH}_{2}$ and Z-L-Asp-Gly- $\mathrm{NH}_{2}$ ). The flow rate was $1 \mathrm{~mL} \mathrm{~min}^{-1}$. UV detection was at $210 \mathrm{~nm}$.

The identities of the purified peptides were determined by RP-HPLC coelution with authentic standards, total hydrolysis followed by amino acid analysis of the hydrolyzates obtained and by ESI-MS analysis. Peptide total acid hydrolysis was performed on a Waters Pico-Tag workstation (Milford, USA). The amino acid analysis of the hydrolyzate was performed with a Beckman model 7300 automated amino acid analyzer (Palo Alto, USA). ESI-MS was performed by direct injection using a Quattro II triple quadrupole instrument (Micromass Ltd., Manchester, UK), positive module, cone voltage of $20 \mathrm{~V}$ and capillary voltage of $3 \mathrm{kV}$.

\section{Size-exclusion liquid chromatography of cPPL}

cPPL (13 mg) was dissolved in $50 \mathrm{mmol} \mathrm{L}^{-1}$ phosphate buffer, $\mathrm{pH} 7.0(1.5 \mathrm{~mL})$ and loaded on a size-exclusion column (Superose 12 10/300 GL, $10 \times 300-310 \mathrm{~mm}, 24 \mathrm{~mL}$, $11 \mu \mathrm{m}$; Amersham Biosciences, Uppsala, Switzerland) connected to a fast protein liquid chromatography (FPLC) system (LKB, Pharmacia, Switzerland). Elution was achieved with $50 \mathrm{mmol} \mathrm{L}^{-1}$ phosphate buffer, $\mathrm{pH} 7.0$ at the flow rate of $0.5 \mathrm{~mL} \mathrm{~min}^{-1}$. UV detection was at $280 \mathrm{~nm}$. All fractions collected were assayed on a microtiter plate against the following chromogenic substrates: $p$ NPP (lipase activity), Bz- $L$-Tyr- $p$ NA (amidase activity) and Bz- $L, D$ Arg- $p$ NA (amidase activity). The microtiter plate reader was a Biotek, model ELX 800.

\section{Results}

Synthesis of Z-L-Asp-Gly-NH $\mathrm{H}_{2}$ using cPPL: efficiency as a function of $n$-hexane content

The relatively low boiling point of $n$-hexane $\left(69{ }^{\circ} \mathrm{C}\right)$ and the very small volume of the reaction media $(20 \mu \mathrm{L})$ strongly suggested that solvent evaporation could occur. Therefore, we monitored the volumes of all reaction media. While significant and moderate evaporation occurred in $100 \%$ and $90 \% n$-hexane, respectively, no reduction of the reaction media volume was observed in lower percentages (0-80\%). Additionally, the acyl acceptor did not dissolve in pure $n$-hexane. Therefore, we did not analyze the reaction media containing $100 \%$ and $90 \% n$-hexane, and considered reliable only the results obtained with $0-80 \%$ $n$-hexane. Consequently, Figure 1 shows the time courses of Z-L-Asp-Gly- $\mathrm{NH}_{2}$ synthesis in buffer containing 0 to $80 \% n$-hexane. It can be seen that the maximum synthesis yields were reached at $70-80 \%$.

Synthesis of Ac-L-Tyr-Gly-NH $\mathrm{NH}_{2}$ in $80 \%$ n-hexane using cPPL and PPPL: efficiency as a function of the ionization state, concentration of the acyl acceptor or temperature

The time courses of Ac- $L$-Tyr-Gly- $\mathrm{NH}_{2}$ syntheses in $80 \% n$-hexane/buffer at $37{ }^{\circ} \mathrm{C}$, shown in Figure 2, reveal 


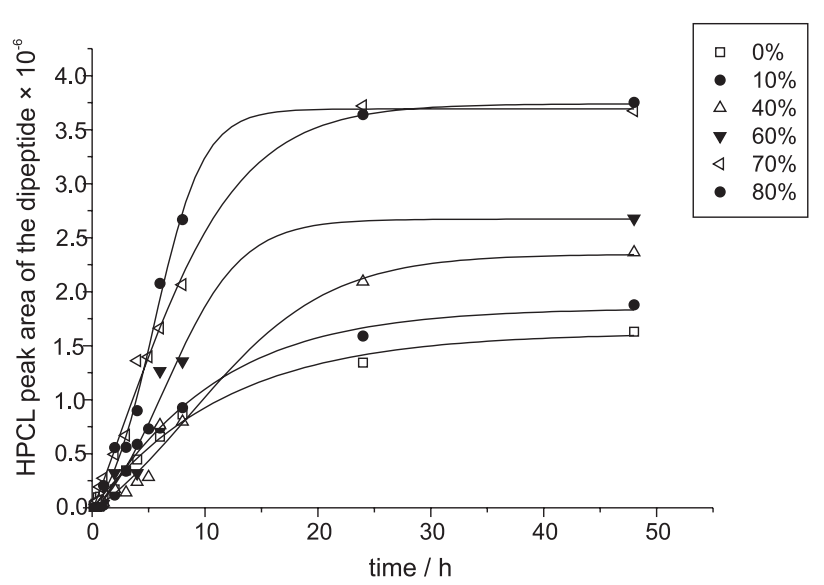

Figure 1. Effect of $n$-hexane content on the synthesis of Z- $L$-Asp-Gly- $\mathrm{NH}_{2}$ using crude porcine pancreatic lipase (cPPL).

that peptide bond was formed with approximately $86 \%$ yield in 5 min when the acyl acceptor was Gly- $\mathrm{NH}_{2}$ (Gly$\mathrm{NH}_{2} \cdot \mathrm{HCl}$ preneutralized with triethylamine) and the enzyme preparation was cPPL or pPPL (entry 1 or 2 in Table 1 ).

Concerning the trials at $37{ }^{\circ} \mathrm{C}$ using pPPL, reduction of Gly- $\mathrm{NH}_{2}$ concentration (7-fold; trial 4 in Table 1), use of Gly- $\mathrm{NH}_{2} \cdot \mathrm{HCl}$ (trial 3) or reduction of Gly- $\mathrm{NH}_{2} \cdot \mathrm{HCl}$ concentration (trial 5) led to coupling yields of 41, 57 or $32 \%$ in $5 \mathrm{~min}$, respectively. On the other hand, a temperature reduction to $22{ }^{\circ} \mathrm{C}$ (trial 6) did not decrease the coupling yield. In buffer at $22{ }^{\circ} \mathrm{C}$ (trial 7), a monophasic reaction medium, the dipeptide synthesis yield reached $67 \%$ in $5 \mathrm{~min}$. When the incubations were prolonged to 24,48 and $72 \mathrm{~h}$, consumption of the dipeptide formed was observed.

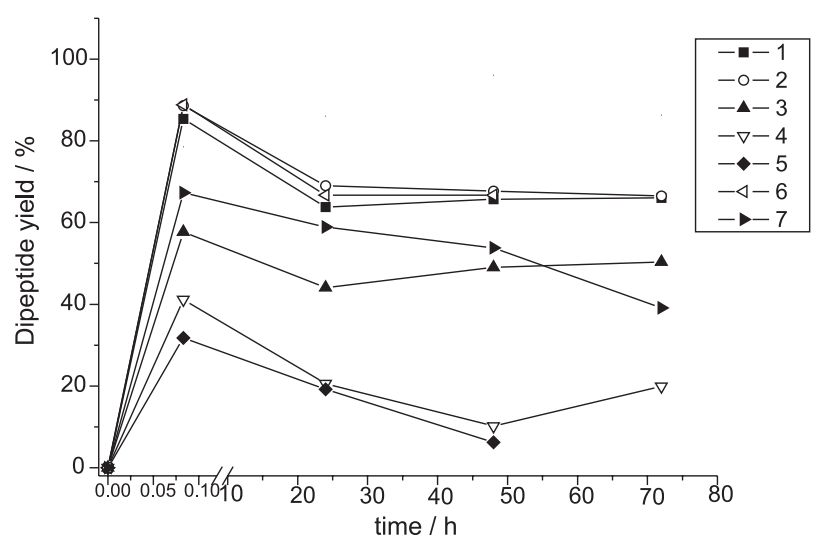

Figure 2. Courses of Ac- $L$-Tyr-Gly- $\mathrm{NH}_{2}$ syntheses using crude and purified porcine pancreatic lipases, entries 1-7 in Table 1.

Synthesis of Ac-L-Tyr-Gly- $\mathrm{NH}_{2}$ in $80 \%$ n-hexane using $\alpha$-chymotrypsin as catalyst

The reaction carried-out in $80 \% n$-hexane/buffer at $37{ }^{\circ} \mathrm{C}$ in the presence of purified $\alpha$-chymotrypsin (trial 8 in Table 1) provided the desired dipeptide with $78 \%$ yield in $5 \mathrm{~min}$.

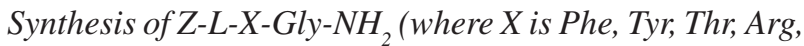
Lys and Asp) in $80 \%$ n-hexane using cPPL

As shown in Figure 3, Z-L-Phe-OMe, Z-L-Thr-OMe, Z- $L$-Arg-OMe and Z- $L$-Lys-OMe also acted as acyl donors in coupling reactions with $\mathrm{Gly}-\mathrm{NH}_{2} \cdot \mathrm{HCl}$ (neutralized with equimolar amount of TEA) in the presence of cPPL. The reactions starting from Z- $L$-Tyr-OMe, Z- $L$-Phe-OMe, Z- $L$ Arg-OMe and Z-L-Lys-OMe were faster than those starting from Z-L-Thr-OMe and Z-L-Asp-OMe. As observed in the Z-L-Tyr-Gly- $\mathrm{NH}_{2}$ synthesis trials, Z-L-Phe-Gly- $\mathrm{NH}_{2}$, Z-L-Arg-Gly- $\mathrm{NH}_{2}$ and Z-L-Lys-Gly- $\mathrm{NH}_{2}$ formed in the reaction media were partially hydrolyzed in long-term incubations (48-51 h).



Figure 3. Courses of Z-X-Gly- $\mathrm{NH}_{2}$ (where $\mathrm{X}=\mathrm{L}-\mathrm{Phe}$, L-Tyr, L-Arg, L-Lys, L-Thr or L-Asp) syntheses using crude porcine pancreatic under the conditions described for entry 1 in Table 1 .

\section{Dipeptide characterization}

Amino acid and ESI-MS analyses of purified dipeptides provided the following results. Found (Z-L-Asp-Gly-NH$)$ : Asp 1.0 (1.0), Gly 1.0 (1.0); [M+H] 323.0 (323.3); Ac- L-TyrGly-NH $\mathrm{NH}_{2}$ Tyr 0.9 (1.0), Gly 1.1 (1.0); [M+ H ${ }^{+} 280.2$ (280.3); Z-L-Arg-Gly-NH $:$ Arg 1.0 (1.0), Gly 0.9 (1.0); [M+H] 365.3 (365.2); Z-L-Lys-Gly-NH : Lys 1.0 (1.0), Gly 1.1 (1.0); [M + $\mathrm{H}]^{+} 337.0$ (336.2); Z-L-Phe-Gly-NH $\mathrm{NH}_{2}$ Phe 1.0 (1.0), Gly 1.1 (1.0); $[\mathrm{M}+\mathrm{H}]^{+} 356.3$ (355.4); Z-L-Tyr-Gly-NH${ }_{2}$ :Tyr 1.0 (1.0), Gly 1.0 (1.0); [M + H] 372.0 (371.4); Z-L-Thr-Gly-NH ${ }_{2}$ : Thr 0.9 (1.0), Gly 1.0 (1.0); [M + H $]^{+} 310.2$ (309.3).

\section{Enzyme activity and analysis}

cPPL was more effective in releasing fatty acids from the triacylglycerides contained in 50\% olive oil (192 U per 
$\mathrm{mg}$ of protein) than pPPL (158 U per mg of protein). Crude PPL showed activity against Bz- $L$-Tyr- $p$ NA (56.2 U per mg of protein), Bz-DL-Arg-pNA (72.5 U per mg of protein) and Z-Gly-L-Phe (24.8 U per mg of protein).

The analysis by one-dimensional SDS-PAGE revealed that, as expected, owing to their source and description, the PPLs presented at least six bands in the gel while the CCLs exhibited only one or two (Figure 4). Surprisingly, pPPL was found to be as heterogeneous as cPPL. Considering the electrophoretic mobility, some of their contaminants migrated similarly to pancreatic $\alpha$-chymotrypsin $(25.2 \mathrm{kDa})$, trypsin $(23.1 \mathrm{kDa})$ and carboxypeptidase A $(35.3 \mathrm{kDa})$ (and, perhaps, carboxypeptidase B) or the lipase-like proteins previously detected in PPL extract ${ }^{29}$ whereas others displayed electrophoretic mobilities compatible with compounds of lower molecular masses (pancreatic peptides or proteolysis products). The component with electrophoretic mobility close to that of the $97 \mathrm{kDa}$-marker may correspond to the cholesterol esterase.

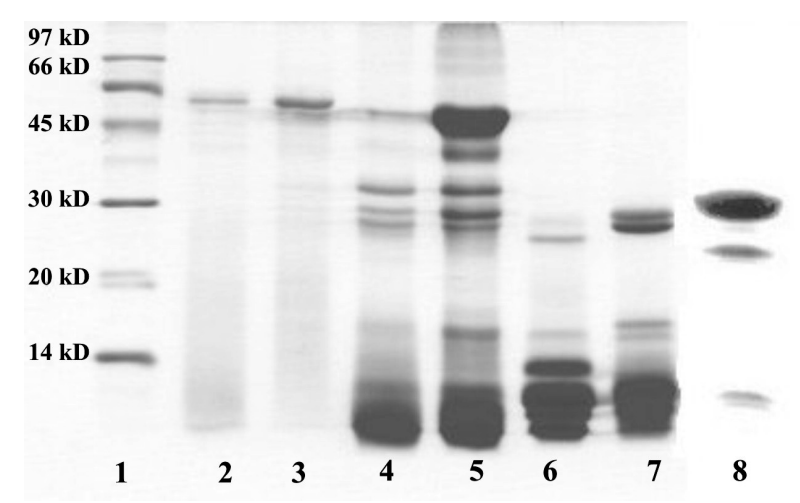

Figure 4. Coomassie blue-stained SDS-PAGE of the lipases employed: lane 1: molecular weight standards $(5 \mu \mathrm{L})$; lane 2: purified Candida cylindracea lipase L-1754 (57.1 kDa; $80 \mathrm{ug}$ ); lane 3: purified Candida cylindracea lipase L-9767 (57.1 kDa; $10 \mu \mathrm{g})$; lane 4: purified porcine pancreatic lipase ( $49.9 \mathrm{kDa} ; 25 \mu \mathrm{g})$; lane 5: crude porcine pancreatic lipase $(49.9 \mathrm{kDa} ; 100 \mu \mathrm{g})$; lane 6: purified bovine pancreatic trypsin $(23.1 \mathrm{kDa}$; $40 \mu \mathrm{g})$; lane 7: purified bovine pancreatic $\alpha$-chymotrypsin $(25.2 \mathrm{kDa}$; $40 \mu \mathrm{g})$; lane 8: phenylmethylsulfonyl fluoride-treated purified bovine pancreatic carboxypeptidase A $(35.3 \mathrm{kDa} ; 89 \mu \mathrm{g})$.

\section{Size-exclusion liquid chromatography of $c P P L$}

The majority of the fractions eluted from the column were active against the substrate $p$ NPP (lipase activity). Only a few of them were active against the chromogenic substrate Bz-L-Tyr-pNA (fractions 67-84) or Bz-D,L-Arg$p$ NA (fractions 67-80).

\section{Discussion}

Although the literature is rich in reports on lipasemediated esterification, amidation, ester hydrolysis and transesterification involving amino acids (as examples, see references 30-33), far fewer articles focus on the use of lipases in peptide bond formation (see references 18 and 19 among the examples). It is noteworthy that the couplings already studied present the following characteristics: (i) they are medium- or long-term reactions (hours or days); (ii) almost all involve soluble substrates in monophasic media; (iii) they occur under a wide variety of experimental conditions, hampering comparisons; iv) the majority employ crude PPL (cPPL), which is particularly surprising because it has been claimed that this is a mixture of enzymes (PPL and contaminant proteases). ${ }^{20,21,29}$ So, the present systematic investigation represents a significant step forward in the evaluation of peptide bond synthesis starting from $N^{\alpha}$-blocked-amino acid esters using commercial PPL preparations.

\section{Development of a biphasic solvent system suitable for dipeptide synthesis using $c P P L$}

It is well documented that, due to conformational changes, some lipases display sharply increased activity at the lipid-water interface or in a heterogeneous medium. ${ }^{34}$ Therefore, it seemed reasonable to seek a biphasic solvent system with the potential to create the interface capable of activating PPL. Based on the recognized high efficiency of cPPL in $n$-hexane, ${ }^{35}$ we considered that mixing this organic solvent with $0.5 \mathrm{~mol} \mathrm{~L}^{-1}$ Tris-HCl buffer, $\mathrm{pH} \mathrm{8}$, at various volume ratios (ranging from 10-90\%), would lead to a suitable solvent system for peptide bond formation using commercial PPLs. Additionally, we were interested in determining the best conditions to be used in the following steps of the present study.

Since amidated amino acids or peptides have been previously used in peptide bond formation catalyzed by CPPL, ${ }^{16-19,36}$ we selected $\mathrm{Gly}-\mathrm{NH}_{2}$. $\mathrm{HCl}$ to act as acyl acceptor in the dipeptide synthesis studied. Based on the fact that Z- $L$ Asp-OMe is a poor substrate for pancreatic proteases that also present esterase activity ( $\alpha$-chymotrypsin and trypsin), this $N^{\alpha}$-blocked- $L$-amino acid ester was chosen to act as acyl donor, so, at least theoretically, involvement of such enzymes in peptide bond formation would not be expected.

The formation of Z-L-Asp-Gly- $\mathrm{NH}_{2}$ (Figure 1) reached the maximum yield in the mixtures containing $70-80 \%$ $n$-hexane, result that was associated with the following positive factors: high enzyme stability, PPL interfacial activation, high substrate solubility and decrease of acyl acceptor $\alpha$-amine pK. Given that these biphasic mixtures have not been previously used as solvents for dipeptide synthesis involving lipase preparations, our work provided the first suggestion that $70-80 \% n$-hexane $/ 0.5 \mathrm{~mol} \mathrm{~L}^{-1}$ Tris-HCl buffer, $\mathrm{pH} 8$, could be suitable for such purpose. 
Besides, it showed that Z-L-Asp-OMe, which has been reported as inappropriate acyl donor for dipeptide synthesis using cPPL, ${ }^{36}$ was suitable under the aforementioned experimental conditions.

Syntheses of dipeptides in $80 \%$ n-hexane/buffer using cPPL or $P P P L$

The fact that we then used Ac- $L$-Tyr-OEt as an acyl donor and observed that trial 1 (Table 1 and Figure 2) furnished Ac- $L$-Tyr-Gly- $\mathrm{NH}_{2}$ with high yield ( $86 \%$ ) in $5 \mathrm{~min}$, indicated that: (i) $80 \% n$-hexane $/ 0.5 \mathrm{~mol} \mathrm{~L}^{-1} \mathrm{Tris}-\mathrm{HCl}$ buffer, $\mathrm{pH} 8$, was suitable for the synthesis of another dipeptide using the PPL preparations selected; (ii) Ac- $L$-Tyr-OEt was a better acyl donor than Z-L-Asp-OMe. Thus, combining a proper solvent system and a proper acyl donor, we reached the highest productivity reported so far for a dipeptide synthesis using a commercial PPL preparation. . $^{14,16,19,36}$

As the efficiency of an enzyme-mediated peptide bond formation may be also affected by other factors such as the sort of enzyme preparation, ionization state and concentration of the reagents and temperature, Ac$L$-Tyr-Gly- $\mathrm{NH}_{2}$ synthesis in $80 \% n$-hexane/buffer was also performed using pPPL, instead of cPPL, in absence or presence of TEA, in two different concentrations of Gly- $\mathrm{NH}_{2} \cdot \mathrm{HCl}$ and/or at 37 or $22{ }^{\circ} \mathrm{C}$. Though peptide bond synthesis was not influenced by temperature change, it was affected by the ionization state and concentration of the acyl acceptor. Thus, in the face of such good results, syntheses of Z-L-X-Gly- $\mathrm{NH}_{2}$ (where X was Phe, Tyr, Thr, Arg and Lys) were performed in $80 \% n$-hexane using cPPL. Interestingly, time courses (Figure 3 ) were consistent with those obtained for the abovementioned syntheses: dipeptide productivity was high only when an $\mathrm{N}$-acyl- $L$-amino acid ester recognized as a good substrate of $\alpha$-chymotrypsin (Z-L-Phe-OMe or Z-L-Tyr-OMe) or trypsin (Z-L-Lys-OMe or Z-L-Arg-OMe) was used as acyl donor. Therefore, these results showed that in the biphasic mixture studied either the low-priced cPPL or the expensive pPPL can be used for the synthesis of a variety of dipeptides. On the other hand, they suggested that $\alpha$-chymotrypsin or trypsin may be involved in the process, which was supported by earlier data $^{31-33}$ and our observation that slow hydrolysis of Ac- $L$ Tyr-Gly-NH ${ }_{2}$, Z- $L$-Phe-Gly-NH ${ }_{2}, \mathrm{Z}-L$-Tyr-Gly- $\mathrm{NH}_{2}, \mathrm{Z}$ - $L$ Lys-Gly- $\mathrm{NH}_{2}$ and Z-L-Arg-Gly- $\mathrm{NH}_{2}$ occurred when their synthesis reactions were prolonged (Figure 2).

Further support to this hypothesis was found by the verification that in $80 \% n$-hexane $/ 0.5 \mathrm{~mol} \mathrm{~L}^{-1}$ Tris- $\mathrm{HCl}$ buffer, $\mathrm{pH} 8$, purified $\alpha$-chymotrypsin catalyzed the synthesis of Ac- $L$-Tyr-Gly- $\mathrm{NH}_{2}$ with very high productivity starting from $\mathrm{Z}-L$-Tyr-OMe (recognized to act as an excellent acyl donor in $\alpha$-chymotrypsin-catalyzed peptide bond syntheses ${ }^{37}$ ).

\section{Analysis of $c P P L$ and $P P P L$}

The indication that proteinases could be involved in dipeptide synthesis using cPPL and pPPL prompted us to analyse these enzyme preparations. Firstly, we employed SDS-PAGE (widely used to evaluate the quality of protein preparations) with the aim to qualitatively show that CPPL and pPPL studied contained the desired lipase and several contaminant proteins. In this context, comparisons should be done only in terms of relative intensities of the bands seen in the same lane (Figure 4). The chemical heterogeneity observed for cPPL was expected and corroborated the data reported by Birner-Grünberger et al. ${ }^{21}$ (who developed a specific method for determining lypolytic enzymes in commercial pancreatic lipase preparations) and by Segura et al..$^{29}$ (who reported the presence of $33 \mathrm{kDa}$ and a $25 \mathrm{kDa}$ proteins in PPL extract). Nevertheless, the observation that the pPPL is as heterogeneous as CPPL was unexpected, hampering any possibility of using it to demonstrate with certainty whether PPL itself is able to catalyze dipeptide synthesis starting from $\mathrm{N}^{\alpha}$-blocked-amino acid esters.

Considering these results, we then assayed only cPPL against synthetic substrates of proteases, ${ }^{25-27}$ an approach used in combination with SDS-PAGE ${ }^{20,21,38}$ to examine enzyme preparations. The high activity of cPPL against Bz-L-Tyr-pNA, Bz-L,D-Arg-pNA and Z-Gly-Phe (usually employed to assay the amidase activity of the proteases chymotrypsin) trypsin and carboxypeptidase A, was consistent with the results reported by Maruyama et al. ${ }^{20} \mathrm{In}$ fact, these authors tested 13 commercial lipases, found that only PPL was active against Bz-L-Tyr-pNA and suggested that the peptidase activity of the commercial PPL was due to contamination by pancreatic $\alpha$-chymotrypsin.

Finally, the existence of amidase activity in cPPL (perhaps due to the presence of $\alpha$-chymotrypsin and trypsin) was confirmed by size-exclusion chromatography. As lipase activity was associated with a high variety of forms (probably aggregates or products of partial degradation) purification of PPL was not possible.

\section{Conclusions}

In this work, at least two dipeptide synthesis trials starting from Ac- $L$-Tyr-OEt and Gly- $\mathrm{NH}_{2}$ (one using cPPL and the other employing pPPL) reached $86 \%$ yield in $5 \mathrm{~min}$ of reaction. ${ }^{39}$ Product consumption was observed when the reactions were prolonged. Similar results were obtained for the synthesis trials using cPPL and starting from of 
Z-L-Phe-OMe, Z-L-Arg-OMe or Z-L-Lys-OMe, but not for those starting from Z-L-Asp-OMe and Z-L-Thr-OMe, and Gly- $\mathrm{NH}_{2}$. Interestingly, Ac- $L$-Tyr-OEt, Z- $L$-Phe-OMe, Z-L-Arg-OMe and Z-L-Lys-OMe, but not Z-L-Asp-OMe and Z-L-Thr-OMe, are good substrates of the pancreatic proteases with esterase activity $\alpha$-chymotrypsin and/or trypsin. cPPL and pPPL used were found to be chemically heterogeneous and present amidase activity. Overall, these results indicated that PPL may not be the main enzyme involved in peptide bond synthesis starting from $N^{\alpha}$-blocked- $L$-amino acid esters and using commercial PPL preparations. Despite it, such data do not contradict the possibility of using cPPL (an inexpensive source of esterases), rather than the purified pancreatic proteases for enantioselective preparation of di, tri- and tetrapeptides under very soft experimental conditions.

\section{Acknowledgments}

This work was funded by the Fundação de Amparo à Pesquisa do Estado de São Paulo (FAPESP, State of São Paulo Research Foundation, grant 00/05410-2). The authors are indebted to Fernanda M. Prado for her technical assistance in mass spectrometry.

\section{References}

1. Sheldon, R.A.; Arends, I.; Hanefeld, U.; Green Chemistry and Catalysis, $1^{\text {st }}$ ed., Wiley Interscience: Weinheim, 2007.

2. Clapes, P.; Adlercreutz, P.; Biochim. Biophys. Acta 1991, 1118, 70.

3. Bordusa, F.; Chem. Rev. 2002, 102, 4817.

4. Kullmann, W.; Enzymatic Peptide Synthesis, $1^{\text {st }}$ ed., CRC Press Inc.: Boca Raton, 1987.

5. Jakubke, H.D.; J. Chin. Chem. Soc. 1994, 41, 355.

6. Kumar, D.; Bhalla, T.C.; Appl. Microbiol. Biotechnol. 2005, $68,726$.

7. Miranda, M. T. M.; Cheng, E.; Muradian, J.; Seidel, W. F.; Tominaga, M.; Bioorg. Chem. 1986, 14, 182.

8. Miranda, M. T. M.; Theobaldo, F. C.; Tominaga, M.; Int. J. Pept. Protein Res. 1991, 37, 451.

9. Klibanov, A. M.; Samokhin, G. P.; Martinek, K.; Berezin, I. V.; Biotechnol. Bioeng. 1977, XIX, 1351.

10. Hänsler, M.; Jakubke, H. D.; J. Pept. Sci. 1996, 2, 279.

11. Miyazawa, T.; Hiramatsu, M.; Murashima, T.; Yamada, T.; Biocatal. Biotransform. 2003, 21, 93.

12. Rall, K.; Bordusa, F.; J. Org. Chem. 2002, 67, 9103.

13. Sears, P.; Wong, C. H.; Biotechnol. Prog. 1996, 12, 423.

14. West, J. B.; Wong, C. H.; Tetrahedron Lett. 1987, $28,1629$.

15. Rojas, C.; Wang, H. H.; Lively, C.R.; Gustafson, W.G.; Schulz, L.O.; McFarland, J. T.; Biochemistry 1989, $28,4475$.
16. Margolin, A. L.; Klibanov, A. M.; J. Am. Chem. Soc. 1987, 109, 3802.

17. Zhang, L. Q.; Zhang, Y. D.; Xu, L.; Li, X. L.; Yang, X. C.; Xu, G. L.; Wu, X. X.; Gao, H. Y.; Du, W. B.; Zhang, X. T.; Zhang, X. Z.; Enzyme Microb. Technol. 2001, 29, 129.

18. Huang, Y. B.; Cai, Y.; Yang, S.; Wang, H.; Hou, R. Z.; Xu, L.; Xiao-Xia, W.; Zhang, X. Z.; J. Biotechnol. 2006, 125, 311.

19. Kawashiro, K.; Kaiso, K.; Minato, D.; Sugiyama, S.; Hayashi, H.; Tetrahedron 1993, 49, 4541.

20. Maruyama, T.; Nakajima, M.; Kondo, H.; Kawasaki, K.; Seki, M.; Goto, M. Enzyme Microb. Technol. 2003, 32, 655.

21. Birner-Grünberger, R.; Scholze, H.; Faber, K.; Hermetter, A.; Biotechnol. Bioeng. 2004, 85, 147.

22. Loffet, A.; J. Pept. Sci. 2002, 8, 1.

23. Tietz, N. W.; Fiereck, E. A.; Clin. Chim. Acta 1966, 13, 352.

24. Ruiz, C.; Falcocchio, S.; Xoxi, E.; Javier Pastor, F. I.; Diaz, P.; Saso, L.; Biochim. Biophys. Acta 2004, 1672, 184.

25. Erlanger, B. F.; Kokowsky, N.; Cohen, W.; Arch. Biochem. Biophys. 1961, 95, 271.

26. Bundy, H. F.; Arch. Biochem. Biophys. 1963, 102, 416.

27. Whitaker, J. R.; Biochem. Biophys. Res. Commun. 1966, 22, 6.

28. Sambrook, J.; Fritsch, E. F.; Maniatis, T. In Molecular Cloning: A Laboratory Manual, $2^{\text {nd }}$ ed., Cold Spring Harbor Laboratory Press: New York, 1989, Ch.18.

29. Segura, R. L.; Betancor, L.; Palomo, J. M.; Hidalgo, A.; Fernández-Lorente, G.; Terreni, M.; Mateo, C.; Cortés, A.; Fernández-Lafuente, R.; Guisán, J. M.; Enzyme Microb. Technol. 2006, 39, 817.

30. Houng, J. Y.; Wu, M. L.; Chen, S. T.; Chirality 1996, 8, 418.

31. Park, O. J.; Park, H. G.; Yang, J. W.; Biotechnol. Lett. 1996, 18 , 473.

32. Conde, S.; López-Serrano, P.; Eur. J. Org. Chem. 2002, 2002, 922.

33. Chen, Z. Z.; Li, Y. M.; Peng, X.; Huang, F. R.; Zhao, Y. F.; J. Mol. Catal. B: Enzym. 2002, 18, 243.

34. Verger, R.; Trends Biotechnol. 1997, 15, 32.

35. Xu, J.; Gross, R. A.; Kaplan, D.L.; Swift, G.; Macromolecules 1996, 29, 3857.

36. So, J. E.; Kang, S. H.; Kim, B. G.; Enzyme Microb. Technol. 1998, 23, 211.

37. West, J. B.; Wong, C. H.; J. Org. Chem. 1986, 51, 2728.

38. Mohamed, S. A.; Fahmy, A. S.; Mohamed, T. M.; Hamdy, S. M.; Comp. Biochem. Physiol., Part B: Biochem. Mol. Biol. 2005, 142, 192.

39. Liria, C. W.; Miranda, M. T. M. In Peptides 2000; Martinez, J.; Fehrentz, J-A., eds.; EDK: Paris, 2001, p. 331.

Received: March 14, 2008

Web Release Date: October 2, 2008

FAPESP helped in meeting the publication costs of this article. 